Edubiotik: Jurnal Pendidikan, Biologi dan Terapan
ISSN 2528-679X (print), ISSN 2597-9833 (online)
Vol. 6, No. 02, September 2021, pp. 108-115
Available online at:
http://ejurnal.budiutomomalang.ac.id/index.php/edubiotik

Research Article OPEN ACCESS

\title{
The characteristics teaching materials of biology laboratory management
}

\author{
Much Fuad Saifuddin*, Etika Dyah Puspitasari
}

Biology Education, Universitas Ahmad Dahlan, Yogyakarta, Indonesia

Email: fuad.saifuddin@pbio.uad.ac.id*, etika.puspitasari@pbio.uad.ac.id

\begin{tabular}{|c|c|}
\hline Article Information & ABSTRACT \\
\hline $\begin{array}{l}\text { Submitted: } 2021-04-21 \\
\text { Accepted: } 2021-11-30 \\
\text { Published: } 2022-01-31\end{array}$ & $\begin{array}{l}\text { The suitable teaching materials will make it easier for students to learn in the } \\
\text { classroom. To present suitable teaching materials, a needs analysis is needed. } \\
\text { This study aimed to determine the types and characteristics of teaching materials } \\
\text { needed in learning biology laboratory management. The survey method was } \\
\text { carried out to students who were randomly selected. The instrument is arranged } \\
\text { in the form of a questionnaire by paying attention to each characteristic indicator } \\
\text { of various teaching materials. The validity of the instrument used a combination of } \\
\text { expert judgment. The questionnaire is distributed via google form to students who } \\
\text { have taken laboratory management courses with a filling period of } 2 \text { weeks } \\
\text { obtained } 123 \text { respondents. The data were analyzed descriptively of quantitatively } \\
\text { and qualitatively. The results showed that the percentage of students who needed } \\
\text { teaching materials for biology laboratory management lectures was } 98 \% \text {; the } \\
\text { characteristics of teaching materials wanted by students included: containing } \\
\text { learning objectives, using simple language, sequenced materials according to } \\
\text { lecture sessions, containing summaries, and providing feedback. Teaching } \\
\text { materials based on existing characteristics can be in the form of modules that are } \\
\text { adapted to the Semester Learning Plan. }\end{array}$ \\
\hline & Keywords: Laboratory management; needs analysis; teaching materials \\
\hline Publisher & How to Cite \\
\hline $\begin{array}{l}\text { Biology Education Department } \\
\text { IKIP Budi Utomo, Malang, Indonesia }\end{array}$ & $\begin{array}{l}\text { Saifuddin, M., \& Puspitasari, E. (2022). The characteristics teaching materials of } \\
\text { biology laboratory management. Edubiotik: Jurnal Pendidikan, Biologi Dan } \\
\text { Terapan, 6(02), 108-115. https://doi.org/10.33503/ebio.v6i02.1298 }\end{array}$ \\
\hline 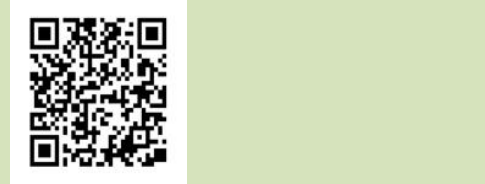 & $\begin{array}{l}\text { Copyright } \odot 2021 \text {, Saifuddin \& Puspitasari. } \\
\text { This is an open access article under the CC-BY-SA license } \\
\text { (c) () () }\end{array}$ \\
\hline
\end{tabular}

\section{INTRODUCTION}

A laboratory is an important facility in supporting the learning process with special equipment and a place to observe various symptoms directly (Bahtiar \& Dukomalamo, 2019) and is a mandatory factor to be utilized to optimize teaching and learning activities (Kertiasih, 2016). Laboratories in schools need to be utilized and managed effectively and efficiently to make a successful learning process at school (Nurhadi, 2018). The laboratory plays a role in developing experimental knowledge and skills (Jeenthong et al., 2014; Şen \& Vekli, 2016). In addition to the process skills, motor skills are required in procedural skills (Burgess et al., 2020) such as activities in the laboratory. Science process skills are used by 
scientists when they study and investigate; the development of basic process skills plays an important role in establishing scientific attitudes (Maranan, 2017), especially the development of interest in the investigation, research, and interest in studying nature in more depth. Therefore, the existence and management of laboratories in schools are very important, especially biology laboratories to make the successful biology learning process.

The management of the biology laboratory involves various human resources in the school, namely the head of the laboratory, laboratory assistants, laboratory technicians, teachers, and students as laboratory users. However, some schools do not have adequate laboratory personnel, which according to Susilo and Amirullah (2018), no laboratory personnel who are an expert in laboratory management is available at the school. In addition, based on the interviews with several schools in the Yogyakarta area, some teachers concurrently serve as laboratory assistants in the laboratory.

The student of the biology education study program needs to have sufficient knowledge related to laboratory management. As a prospective teacher, it is necessary to develop the ability to master laboratory management skills (Chusni \& Hasanah, 2018). The student of biology education learns the basics of biology laboratory management at the high school level through lectures, and the biology education study program provides biology laboratory management courses. A good learning process can be managed if it is supported by various factors including the learning model used by lecturers (Sartika, 2018). In addition to the learning model, the teaching material used is an important factor that supports the learning process. Teaching materials play an essential role in learning by providing initial knowledge regarding the studied material, especially if there is relatively little interaction between lecturers and students, as in the current pandemic. Furthermore, teaching materials stimulate the students to be more independent, enabling them to learn anytime and anywhere and encouraging the realization of lifelong learning (Recker et al., 2004).

The development of teaching materials shall be made by considering the learning problems experienced, the targets (students), and competencies to be achieved (Pratiwi et al., 2017). However, it is often that many available teaching materials are not following the needs (Arsanti, 2018). The development of teaching material shall reflect the updated and development of Science and Technology (Rohmani et al., 2017), relevance, complexity, rational/scientific, functional, and comprehensive (Arsanti, 2018). According to Pribadi and Sjarif (2010), in designing the development of teaching materials, it is necessary to observe several components, such as the structure, content or learning materials, presentation strategies, and presentation of teaching materials, furthermore the teaching materials developed also need to consider the evaluation of student learning success and any feedback. Thus, the development of teaching materials shall consider the aspects of need and the accuracy of their use.

Based on the search from various references, there are no references or teaching materials that are compatible with the biology laboratory management course. Most of the references emphasize laboratory management in hospitals or research laboratories so that they are not following the needs of the learning design of biology laboratory management courses intended for the high school biology laboratories. Meanwhile, various studies and references related to high school biology laboratories (Adilah et al., 2021; Astuti, 2020; Balqis et al., 2018; Simatupang \& Sitompul, 2018) mostly emphasize the management of laboratory facilities and infrastructure, while management aspects are not limited only to the management of facilities and infrastructure. This research contributes to determining the form of teaching materials developed for biology laboratory management courses under the characteristics and needs of biology laboratory management courses. 


\section{RESEARCH METHODS}

This descriptive study was performed by survey at the Biology Education Study Program, FKIP UAD. The study involved student respondents who had taken biology laboratory management courses, with a total sample of 123 respondents who were determined through random sampling. The collection of data was conducted using a questionnaire compiled through google form with a total of 13 questions related to biology laboratory management references, components of teaching materials, language in teaching materials, and format of teaching materials. The questionnaire instrument has gone through a validation process by three experts having expertise in teaching materials and evaluation and is declared valid for use. The respondent data in the form of nominal and narrative were then descriptively quantitatively and qualitatively analyzed.

\section{FINDING AND DISCUSSION}

The research data was obtained using a questionnaire instrument that has passed the validity testing, three experts have provided input to the questionnaire which is summarized in Table 1.

Table 1. Notes to Instrument Validation

\begin{tabular}{|c|c|}
\hline Expert & Notes \\
\hline Expert $A$ & $\begin{array}{l}\text { It is necessary to explore student arguments regarding the products used today, some items } \\
\text { require correction of sentence redaction into statements }\end{array}$ \\
\hline Expert B & Redundant questions, change the word 'printed book' to offline and the word 'PDF' to online \\
\hline Expert C & $\begin{array}{l}\text { It is advisable to consider the student's learning style and level of independence; a } \\
\text { question/statement regarding whether or not the product is contextual shall be included }\end{array}$ \\
\hline
\end{tabular}

Based on Table 1, improvements were made to the research instrument and then used to collect data on the student needs for teaching materials in laboratory management courses. The data collection results were obtained by demographics of respondents from the class of 2016 and Class of 2017, both Classes have taken biology laboratory management courses so that the information provided is based on the personal experience of each respondent. The number of respondents was 123 respondents consisting of 112 women and 11 men. Ownership of references is essential to support readiness in participating in learning, the results of the analysis related to ownership of references for biology laboratory management courses are still minimal as shown in Figure 1.

Based on Figure 1, shows that the students do not have adequate references to take biology laboratory management lectures, the ownership of references has an important role in student's readiness to take part in the learning process. According to Recker et al. (2004), the existence of teaching material potentially makes the students independent learners, which enables them to learn anytime and anywhere and allows them to select the order of the material to be studied. The students may prepare themselves with basic knowledge before attending lectures, references are not only provided by lecturers (teachers) but also are sought independently by students. Reference-seeking skills are important for the students, but often the students' skills to seek references are limited (Mao et al., 2020). The students often experience difficulties in findings references independently due to the lack of availability of references (Brown et al., 2015), both in digital form (on the internet) or in books, this difficulty is experienced by students when they are searching for biology laboratory management references (Figure 2). The difficulties occur since learning resources related to laboratory management are still fragmentary, for example, learning resources on laboratory management are sourced from laboratory management in general, not specifically referring to laboratories in schools. 


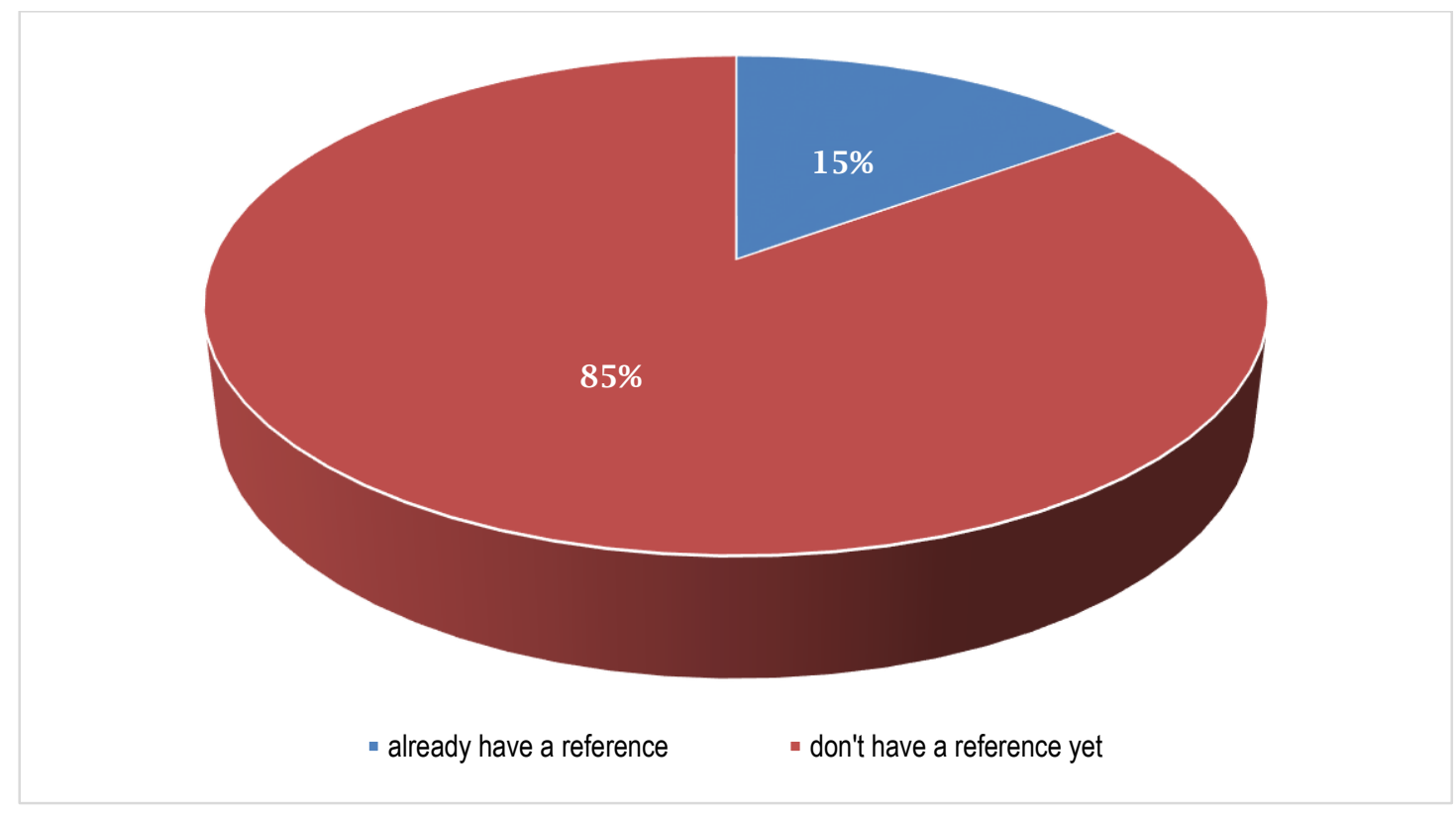

Figure 1. Ownership of Reference Analysis

It is very unfortunate that most of the literature on the management of laboratories in schools mainly discusses the management of facilities and infrastructure. Whereas laboratory management is not only limited to the management of facilities and infrastructure, it may also include human resources, work safety and security, and laboratory waste management. The need for teaching materials in biology laboratory management is not only based on the lack of students who have references (Figure 1) and the difficulty of students in finding references (Figure 2), but also $98 \%$ of the students express the need for references in the form of teaching materials (Figure 3 ). The student's difficulty in finding references indeed causes a delay in the learning process (Ayu, 2020; Brown et al., 2015), because students cannot independently carry out the learning process. Only $2 \%$ of students stated that they did not need teaching materials in learning laboratory management courses. Therefore, lecturers as facilitators should be able to provide learning resources that are easily accessible to students. It is even better if the lecturer can develop teaching materials that follow the prepared semester learning plans (RPS) to make the learning process easier. Teaching materials developed in a course are expected to be more effective and more suitable with the needs to achieve the expected competencies (Burge, 2019).

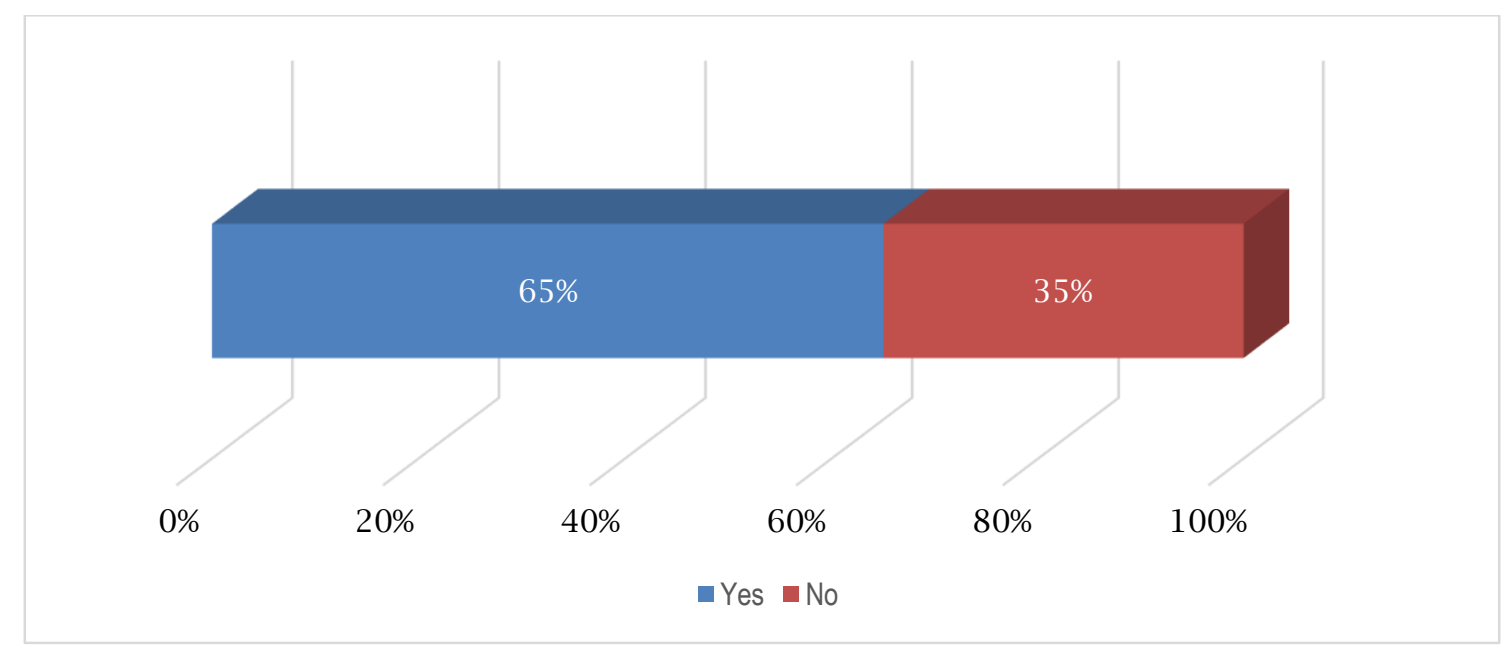

Figure 2. The Difficulty of Students in Finding References

Saifuddin \& Puspitasari - The characteristics teaching materials of biology laboratory ... 


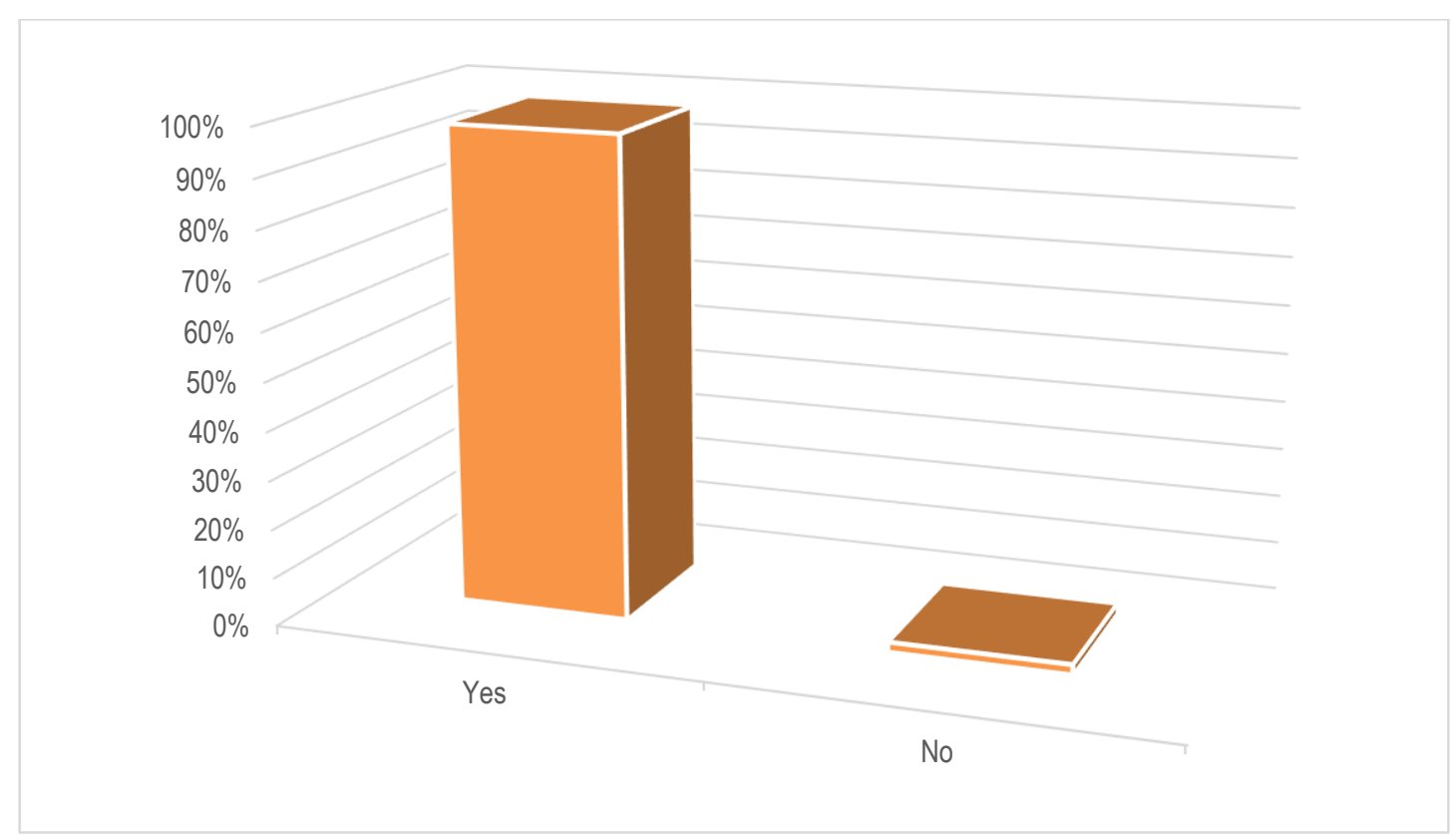

Figure 3. Student Needs for Biology Laboratory Management Teaching Materials

The preparation of teaching materials on biology laboratory management shall include the characteristic desired by the students to optimize the learning process. The characteristics of learning materials based on the student's needs are shown in Table 2 .

Table 2. Characteristics of Teaching Materials Based on The Student's Needs

\begin{tabular}{cc}
\hline Criteria & Response (\%) \\
\hline Teaching materials provided in simple language & 92 \\
Teaching materials contain learning objectives & 98 \\
Teaching materials present sequential material according to the lecture session & 97 \\
Teaching materials contain summaries & 91 \\
Teaching materials contain Feedback & 83 \\
\hline
\end{tabular}

Teaching materials are prepared according to the needs of students as learners, the suitability of teaching materials to their needs can help students understand the lecture material. Pursuant to the analysis of the characteristics of teaching materials based on the student's needs, it shows that as many as $92 \%$ of students wish to have teaching materials provided in simple language. Simple language and the use of commonly used terms will make it easier for students to understand and study the teaching materials independently (El Mhouti et al., 2013; Maryani et al., 2019). The language in a text (book) has an important role in building one's knowledge, the use of simple language in teaching materials is expected to help students understand the taught material better. In addition, students also wish to have learning objectives included in the teaching materials developed (Table 2). The learning objectives in teaching materials allow the students to figure out the goals in learning the materials provided in such teaching materials. The learning objectives in teaching materials also help the lecturer to evaluate the learning objectives that have been achieved, especially at the end of a lecture (El Mhouti et al., 2013).

The material presented in the developed teaching materials shall be arranged in sequence according to the sequence of the lecture sessions. Therefore, the prepared teaching materials shall be based on the lesson plans for the compiled courses. Although specific teaching material is available, the students are expected to study independently and determine which material to read or learn first. However, $97 \%$ of students wish to have teaching materials to be prepared according to the sequence of 
the lecture sessions. In addition to containing learning objectives, $91 \%$ of students wish to have teaching materials that include summaries. The availability of summaries at the end of every material discussion will make it easier for the students to understand the material as a whole and acknowledge the integration of each material presented. The students also require feedback in any teaching materials, which $83 \%$ of students want the teaching materials developed to contain feedback.

Based on the results of the analysis of student needs, the type of teaching materials that are suitable to be used in biology laboratory management study is a module, availability of module allows the student to study independently (Bradley \& Putnick, 2012; El Mhouti et al., 2013; Hartanti et al., 2019). According to Pratiwi et al. (2017), the use of modules in the learning process not only emphasizes teacher activities but also encourages the students to be actively involved in and create an independent learning process. The modules designed by a Teacher shall contain: 1) the objectives and aspirations of the module for students and its delivery to the students; 2) constructively aligned modules (students actively build their understanding to have teaching and assessments align with the desired outcomes); 3) Consider the characteristics of the content (Burge, 2019). The use of modules as teaching materials may encourage the student motivation to learn, provided that the modules shall be developed according to the characteristic of the module, namely: a) Self-instructional, b) Self-Contained, c) Standalone, d) Adaptive and e) User-friendly (Rahdiyanta, 2016). Such characteristics shall be one of the references in developing modules as teaching materials in the biology laboratory management course.

\section{CONCLUSION}

Students wish to have modules as teaching materials for biology laboratory management courses which consistent with the Semester Learning Plan. The modules shall contain learning objectives, summaries, and feedback. In addition, the modules shall be arranged in simple language and the material shall be prepared following the sequence of lectures. This research can be used as a basis for reference in developing teaching materials for biology laboratory management courses.

\section{ACKNOWLEDMENT}

The authors would like to thank the Research and Community Service Institute (LPPM) Universitas Ahmad Dahlan for funding this research (No: PD-106/SP3/LPPM-UAD/2020).

\section{REFERENCES}

Adilah, M., Setiadi, A. E., \& Kahar, A. P. (2021). Analisis standarisasi laboratorium biologi Sekolah Menengah Atas (SMA) di Kota Pontianak (The analysis of standardization of biology laboratory at senior high school in Pontianak). JURNAL ILMIAH DIDAKTIKA: Scientific Media of Education and Teaching, 21(2), 195-207. https://doi.org/10.22373/jid.v21i2.5995

Arsanti, M. (2018). The development of teaching materials for creative writing courses containing religious character education values for students of Indonesian Language and Literature Education, Faculty of Teacher Training and Education, UNISSULA. KREDO : Scientific Journal of Language and Literature, 1(2), 71-90. https://doi.org/https://doi.org/10.24176/kredo.v1i2.2107

Astuti, R. (2020). Smart, careful and safe laboratory management. CV Jejak.

Ayu, E. D. (2020). The analysis of the difficulties of students of the biology education program of Faculty of Teacher Training and Education UMS in writing essay during the covid-19 pandemic in the academic year of 2019/2020 [Essay, Universitas Muhammadiyah Surakarta]. Surakarta. http://eprints.ums.ac.id/84998/ 
Bahtiar, B., \& Dukomalamo, N. (2019). Basic science process skills of biology laboratory practice: improving through discovery learning. Biosfer: Journal of Biology Education, 12(1), 83-93. https://doi.org/10.21009/biosferjpb.v12n1.83-93

Balqis, T., Hamidah, A., \& Aina, M. (2018). The analysis of the biology laboratory management at senior high school in Batanghari Regency, Jambi Province. Edu-Sains: Journal of Mathematics and Natural Sciences Education, 7(1), 16-22. https://doi.org/10.22437/jmpmipa.v7i1.7278

Bradley, R. H., \& Putnick, D. L. (2012). Housing quality and access to material and learning resources within the home environment in developing countries. Child Dev, 83(1), 76-91. https://doi.org/10.1111/j.1467-8624.2011.01674.x

Brown, M., Hughes, H., Keppell, M., Hard, N., \& Smith, L. (2015). Stories from students in their first semester of distance learning. The International Review of Research in Open and Distributed Learning, 16(4). https://doi.org/10.19173/irrodl.v16i4.1647

Burge, A. (2019). How to design effective teaching modules. UACES: University Association for Contemporary European Studies. https://www.uaces.org/resources/articles/how-design-effec tive-teaching-modules

Burgess, A., van Diggele, C., Roberts, C., \& Mellis, C. (2020). Tips for teaching procedural skills. BMC Med Educ, 20(Suppl 2), 458. https://doi.org/10.1186/s12909-020-02284-1

Chusni, M. M., \& Hasanah, A. (2018). The influence of laboratory management skills and scientific literacy on the readiness of prospective physics teachers. Scientific Journal of Physics Education, 6(3), 325-335. https://doi.org/10.20527/bipf.v6i3.5222

El Mhouti, A., Nasseh, A., \& Erradi, M. (2013). How to evaluate the quality of digital learning resources? International Journal of Computer Science Research and Application, 3(3), 27-36. https://www.researchgate.net/

Hartanti, D., Sajidan, S., \& Prayitno, B. A. (2019). Development of the discovery learning module on plant structures by utilizing the local potential of umbul tlatar to improve self-regulation and environmental awareness of high school students. Jurnal Bioedukatika, 7(1). https://doi.org/10.26555/bioedukatika.v7i1.12532

Jeenthong, T., Ruenwongsa, P., \& Sriwattanarothai, N. (2014). Promoting integrated science process skills through betta-live science laboratory. Procedia - Social and Behavioral Sciences, 116, 3292-3296. https://doi.org/10.1016/j.sbspro.2014.01.750

Kertiasih, N. L. P. (2016). The role of the educational laboratory to support the dental nursing lecture process at the Denpasar Health Polytechnic. Dental Health Journal, 4(2), 59-66. https://ejournal.poltekkes-denpasar.ac.id/index.php/JKG/article/view/510

Mao, Z., Wu, T., Zhang, J., Feng, D., Chen, J., Liu, C., Qi, S., Li, Q., Kang, H., \& Zhou, F. (2020). Performance of Chinese medical postgraduate students in literature searching: a two-center survey and analysis. Ann Transl Med, 8(21), 1453. https://doi.org/10.21037/atm-20-6932

Maranan, V. M. (2017). Basic process skills and attitude toward science: Inputs to an enhanced students' cognitive performance [Thesis, Laguna State Polytechnic University]. San Pablo City. https://files.eric.ed.gov/fulltext/ED579181.pdf

Maryani, I., Lestari, N. W., \& Saifuddin, M. F. (2019). Magazine based on guided inquiry-an Innovation to overcome natural science learning difficulties in elementary schools. Pedagogika, 136(4), 51-66. https://doi.org/10.15823/p.2019.136.4

Nurhadi, A. (2018). Laboratory management in an effort to improve the quality of learning. Tarbawi: Jurnal Keilmuan Manajemen Pendidikan, 4(1), 1-12. https://doi.org/10.32678/tarbawi.v4i01.832

Pratiwi, P. H., Hidayah, N., \& Martiana, A. (2017). Development of HOTS (Higher Order Thinking Skills)oriented sociology learning assessment course modules. Jurnal Cakrawala Pendidikan, 36(2), 201-208. https://doi.org/10.21831/cp.v36i2.13123

Pribadi, B. A., \& Sjarif, E. (2010). Constructivistic approach and development of teaching materials in distance learning system. Journal of Open And Distance Education, 11(2), 117-128. https://jurnal.ut.ac.id/index.php/jptj/article/view/461 
Rahdiyanta, D. (2016). Module Preparation Technique [Suplementary research]. Universitas Negeri Yogyakarta. http://staff.uny.ac.id/sites/default/files/penelitian/dr-dwi-rahdiyanta-mpd/20-teknikpenyusunan-modul.pdf

Recker, M. M., Dorward, J., \& Nelson, L. M. (2004). Discovery and use of online learning resources: Case study findings. Journal of Educational Technology \& Society, 7(2), 93-104. https://www.jstor.org/ stable/jeductechsoci.7.2.93

Rohmani, M., Amin, M., \& Lestari, U. (2017). Analysis of the need for research-based teaching materials in biotechnology in the medical field for undergraduate students of Biology Education, State University of Malang based on the ADDIE development model. Seminar on Postgraduate Science Education, State University of Malang, Malang, Indonesia.

Sartika, R. P. (2018). Implementation of the problem based learning model in improving students' understanding of concepts in laboratory management courses. Edusains, 10(2), 197-205. https://doi.org/10.15408/es.v10i2.7376

Şen, C., \& Vekll, G. S. (2016). The impact of inquiry based instruction on science process skills and selfefficacy perceptions of pre-service science teachers at a university level biology Laboratory. Universal Journal of Educational Research, 4(3), 603-612. https://doi.org/10.13189/ujer. 2016.040319

Simatupang, A. C., \& Sitompul, A. F. (2018). The analysis of biology laboratory facilities and infrastructure and implementation of biology practicum activities in support of class XI class biology learning. Jurnal Pelita Pendidikan, 6(2), 109-115. https://doi.org/10.24114/jpp.v6i2.10148

Susilo, S., \& Amirullah, G. (2018). Management and utilization of school laboratories for Muhammadiyah teachers in East Jakarta. Jurnal SOLMA, 7(1), 127-137. https://doi.org/10.29405/solma.v7i1.2380 